\title{
Kaleidoscope
}

\section{The Issue of the Strengthening Public Role in Making Environmentally Significant Decisions at the International and National Level, with Special Reference to Russian Legislation}

\author{
Aleksey Pavlovich Anisimov - Anatoliy Yakovlevich Ryzhenkov
}

\begin{abstract}
In the 21st century new environmental threats ignoring states' borders have appeared. They include the negative impact of nanotechnologies on the environment, the interference in hydro-meteorological processes and some others. The subject of this research is the effect of international and national regulations, court decisions and other law enforcement practices on the field of public participation in making environmental decisions. The purpose of this paper is to formulate the measures for further development of the public participation principle and improvement of the legal protection of the environment as a whole. As a result, key terms, international and national acts, individual problems of enforcement are characterized. Based on the analysis of national legislation and $\mathrm{EU}$ directives the authors justify the necessity to develop the international instruments governing intervention in natural processes, and interpret a number of environmental evaluation and legal categories.
\end{abstract}

Key words: public, environmentally significant decisions, environmental control, hydro-meteorological processes, nanotechnologies

\section{INTRODUCTION}

The problem of strengthening the public role in solving environmentally significant problems, which influence the life quality and health of present and future generations, has no national boundaries, and is to some extent relevant for all countries in the world. A score of international treaties ${ }^{1}$ and a great number of domestic regulations are focused on solving this problem. There is an extensive practice on various aspects of public participation in making environmentally significant decisions at the European Court of Human Rights, and other international and national courts. Despite some progress in legal regulation and the

${ }^{1}$ From the international instruments one should refer first of all to the Espoo Convention on Environmental Impact Assessment in Transboundary Context from 1981 and the Aarhus Convention on Access of Information, Public Participation in Decision-making and Access to Justice in Environmental Matters concluded in 1998.

Aleksey Pavlovich Anisimov, Professor of the Chair of Civil Law Volgograd Institute of Business, Doctor of juridical sciences;

Anatoliy Yakovlevich Ryzhenkov, Professor of the Chair of Civil Law Volgograd Institute of Business, Doctor of juridical sciences

(Received: 01.12.2013; revision received: 23.01.2014; accepted: 31.01.2014) 
protection of human rights some unresolved issues related to the occurrence of new environmental threats still exist. This means there is the need to develop new methods and modalities for the participation of the world community in solving these issues.

The subject of this study is the effect of international and national regulations, court decisions and other legal practice on the public participation in environmental decisionmaking. The purpose of this article is to formulate measures for the further development of the public participation principle in environmental decision-making at the international and national levels, as well as the improvement of the environment protection in general. During the course of the research, comparative-legal, formal-logical and statistical methods were used as well as the method of the system analysis. As a result, the main terms of international and national acts were characterized, and certain problems of law enforcement were identified. The authors have attempted to provide a comprehensive vision of the research subject, making an overview of the present and future issues faced.

The hypothesis of the study is that the legal regulation involving public participation in decisions that have had an impact on the environment at the international and national level looks quite convincing. There is also a successful legal practice in developed European countries. The situation of ensuring the participation of the public in solving of environmental issues in developing countries is much worse, including the Russian Federation. Thus, in spite of all these differences new environmental threats have appeared in the 21 st century, which have known no bounds. It will only be possible to solve these problems through the collective efforts of all countries of the world.

Issues discussed in this article have already appeared in the literature of the scientific community. Certain issues of public environmental law have been contemplated in the writings of S.A. Bogolyubov, M.M. Brinchuk, M.V. Vasilyeva, T.I. Makarova, I.S. Nazarova, A.A. Pavlushina, Yu.A. Tikhomirov, O.V. Trudova, O.A. Yakovleva, and E.Yu. Yakovlev. E.A. Belokrylova, A.K. Veselov, M.T. Gogaeva, E.A. Zhemchuzhnova, N.S. Ivanchenko, V.F. Petrenko and other scientists have actually specifically considered public participation in making environmentally significant decisions.

Meanwhile, the existing scientific legal research regarding public participation in environmental issues has had either an international or domestic aspect. The authors of this article tried to show a different "snapshot of the problem", to link international and national regulations of public participation in solving environmental issues with respect to the new environmental threats that have arisen in the 21 st century.

\section{INTERPRETATION OF THE EVALUATION CATEGORIES (PUBLIC PARTICIPATION, ENVIRONMENTALLY SIGNIFICANT DECISIONS, ETC.) IN RUSSIAN LEGISLATION}

The effectiveness of the legal regulation of any public relations' area is directly stipulated by a clear understanding of the subject of the regulation. However, the description of this subject depends on the development of the conceptual apparatus of a single legal act or the entire legal system.

The use of undefined terms in regulations and enforcement practices, whereby interpretation is ambiguous, complicating the implementation of legal regulations, gives rise to various conflicts. This trend has occurred in all countries of the world.

However, the current state of public relations which is becoming more and more complicated from year to year makes it impossible to describe in detail the nature of certain legal categories because of their complexity and multifaceted use. This fact leads to the 
appearance of "evaluation categories" - legal terms, the exact meaning of which is determined by the respective law enforcement authority based on the circumstances of the case, rather than by legislative acts. The mere existence of such categories is by no means an indication of the imperfection of the national legal system, or the lack of an international instrument. As such, the evaluation categories are presented in the regulations of both developed and developing countries. For example, in some EU Directives the mention of "reasonable terms ensuring the adequate time to inform the public and to prepare and involve the public concerned in the decision-making on environmental issues" are encountered. ${ }^{2}$ Only in one mentioned regulation do we see just three evaluation categories.

In this regard, it appears that the presence of the evaluation categories in characterizing the legal system is not so important but more so are the trends of law enforcement, and judicial objectivity in their interpretation.

The terms "public" and "environmentally significant decisions", which are under review in this article, are very typical evaluation categories in the national (Russian) and international law.

There is no definition of "public" in Russian law, and law enforcement agencies usually refer to environmental public associations or citizens residing in a particular area (e.g. city neighborhood, where the construction of an environmentally hazardous facility is planned). The same is true with respect to "environmentally significant decisions". This term is absent in Russian law, but based on the context of the legislation it is clear that they are "decisions that can have a positive or negative impact on the environment". The absence of a clear legal definition of the terms under consideration led to a number of theoretical scientific discussions.

M.I. Vasilyeva believes that the importance of public participation is not limited to a utility function with respect to human rights, but consists in its ability to indirectly influence the quality of the environment. Public activity is an important incentive to improving law and management. In this coordinate system, the effectiveness and even the sense of participation is associated with its implementation in the period just prior to making environmentally significant decisions, otherwise, the procedure becomes a decoration (Vasilieva 2003).

The principle of public participation in decision-making is especially common in respect of environmental law when it is referred to as protecting the public interest. Yu.A. Tikhomirov defines the public interest as an "interest of a public community recognized by the state and guaranteed by the law, the satisfaction of which is the guarantee of its existence and development" (Tikhomirov 1995: 55).

The "public" category is sometimes equated with "public organizations". This comparison is unacceptable. The public is a multiple-aspect concept, and public organizations represent de jure an active sector of the public, with its parts, citizens, united to solve specific problems (Belokrylova, 2007). It follows that, while making environmentally significant decisions, people who have a business or commercial interest should be excluded from the "public" (Brinchuk 2000).

Thus, the principle of public participation in making environmentally significant decisions is provided through the cooperation of public authorities, legal entities and the

2 See p. 7 Art. 15 of the Directive of the European Parliament and Council of the European Union 2012/18/ES dd. July 4, 2012 on the control of major accident hazards involving dangerous substances, amending and subsequently annulling Directive 96/82/EC of the European Council. 
public; the mutual assistance of the public and public authorities is undergone in the development of the civil society in order to protect the environment, natural resource management, and environmental safety (Vinokourov-Vystorobets 2010).

Reflecting on environmental law and the implementation of the principle of public participation, it is necessary to analyze the forms and methods of participation. Most modern Russian scientists agree that the basic form of this participation is public environmental control. According to the ideas of V.F. Petrenko "public environmental control is a concept comprising all activities of citizens and environmental organizations on the implementation of constitutional and other legal rights to a healthy environment and compensation for damages to health and property" (Petrenko 1998).

A.K. Veselov includes a list of activities in this concept, including "participation in making environmentally significant decisions" (Veselov 2005).

In our view, public environmental control cannot be considered to be a generic category for all types and forms of public participation in environmental protection. Public environmental control is a type of activity exactly regulated by environmental legislation, which manifests itself in the form of a warning (utilizing public environmental expertise for projects' planned activities) or in the form of current control (over the state of the environment, including the identification of waste disposal sites, adherence to environmental requirements at construction, etc.). Such monitoring should be present at all stages of the economic activities (construction, commissioning, operation, reconstruction, etc.) of environmentally hazardous facilities. Meanwhile, the types and forms of public participation in making environmentally significant decisions are not limited to the preventive and current environmental controls.

In order to formulate the specific types and forms of such public participation, it is necessary to determine the content of another evaluation category, namely, "environmentally significant decisions". In the scientific literature it is suggested that this means the decisions made by authorities and business entities, the implementation of which is related to the impact on the environment, and affects the environmental human rights (Belokrylova 2006).

But how can we determine the extent to which decisions made by public authorities and requiring the intervention of the public influence the environment? Nowadays there are no comprehensive criteria for determining the category in Russian law. We can only speak about the objects, whose scale of construction or intervention in natural processes requires licenses, certificates of state examination or other legal documents specified in the respective environmental laws.

Undoubtedly, a number of such projects concerning the construction of environmentally hazardous facilities will be referred to them (for example, the processing and destruction of chemical weapons, projects that require the destruction of forests, etc).

It is worth agreeing to ideas of E.A. Belokrylova, who proposed the principles of public participation in the stages of development, making and implementation of environmentally significant decisions: the preventive principle (involving the public early on in the decision-making process which also includes the dissemination of information to the public), the "feedback" principle (reaction of a party that makes decisions on the results of the process of public participation), the principle of mandatory documenting of events for public participation, and their results, the principle of responsibility of parties concerned for the failure or improper performance of public participation procedures, the availability principle of the public participation procedure (Belokrylova 2007).

Meanwhile, the implementation of public participation in making environmentally significant decisions in Russia and most countries of the former Soviet Union has been 
hindered by a number of objective and subjective factors. On the one hand, various procedural issues of public activities remain unsettled (for example, the rules on recording the results of public discussion while performing Environmental Impact Assessments, rights, obligations, responsibilities of public controllers, guarantees to provide the necessary information by the respective public authorities and private organizations). On the other hand, in spite of the fact that the prestige of public (voluntary) activities is growing in modern Russia, the number of participants in public environmental groups still remains extremely low. There are also questions regarding the training of citizens willing to participate in such decisions.

The special question is whether the structures created at the initiative of state authorities (local governments), for example, the Public Chambers of the Russian Federation and the subjects of the Russian Federation, which sometimes try to act as mediators in disputes between citizens, governments and businesses structures, are in fact "public".

Thus, in the Russian law the evaluation category "public" is generally understood as a set of civil society subjects, which includes citizens and the system of non-government (public) legal entities, having rights, freedoms and responsibilities in the field of environmental protection and rational use of natural resources provided by environmental law.

"Environmentally significant decisions" result from alternative business or other practices that take into account the use of natural resources and/or negative impacts on nature, based on the consideration of environmental and legal requirements that prevent, or reduce, the negative impact of these activities on the environment (Gogaeva 2011).

\section{LEGAL REGULATION OF PUBLIC PARTICIPATION IN ENVIRONMENTAL ISSUES IN INTERNATIONAL AND EUROPEAN LAW}

\subsection{International cooperation in the field of public participation in environmentally significant issues}

As a principle of international cooperation in the field of environmental protection, public participation as a means to solve environmentally significant problems is specified in a number of international treaties and documents, including the Stockholm Declaration 1972, Rio Declaration 1992, and some others.

However, the category of "public" and the principles of its participation in making environmentally significant decisions are most consistently reflected in the Convention on Access to Information, Public Participation in Decision-making and Access to Justice in Environmental Matters (Aarhus Convention, Aarhus, June 25, 1998).

Two evaluation categories are differentiated in this convention: "public" and "public concerned".

One or more natural persons or legal entities are meant by the term "public" in the Convention and, in accordance with national legislation or practice, also included are their associations, organizations or groups.

The "public concerned" means the public involved or likely to be involved in decisionmaking on issues related to the environment, or having an interest in this process; for the purposes of this definition, non-governmental organizations promoting environmental protection and meeting any requirements under national law are deemed to be organizations concerned. 
The inclusion of legal entities as a component of the "public" sometimes meets with opposition in legal literature. So, E.A. Belokrylova considers "that the integration of legal entities with the term 'public' defined in the Convention is highly controversial. Legal entities do not have personalized character, cannot be individually identified..." (Belokrylova 2007).

Meanwhile, the reference to legal entities in the Convention is essential for the selforganization of citizens, allowing them to combine efforts to defend their environmental rights, and that deserves just support.

The Convention does not reveal the contents of the category "environmentally significant decisions", although based on the context of its rules we can conclude that such decisions touch upon three areas of public relations:

1. Public participation in making decisions on specific activities. The public concerned is adequately, timely and effectively informed, depending on the circumstances, either by public notice or individually at a very early stage of decision-making on issues related to the environment, including: the specific activities and applications on which the decision will be made; the nature of possible decisions or draft decisions; the state authority responsible for decision-making; the specified procedure, etc. Relevant activities are listed in Annex 1 to the Convention, and include power generation facilities, metal production and processing, waste treatment and disposal, etc.;

2. Public participation in the solving of issues concerning environmental plans, programs and policies;

3. Public participation in the development of self-executing regulations and/or generally applicable legally binding normative instruments.

Thus, we can doctrinally derive the following definition: "environmentally significant activity" is an activity that involves the construction or reconstruction of industrial facilities, the operation of which is hazardous to the environment, and the development of environmental plans, programs and regulations.

\subsection{Legal regulation of public participation in environmentally significant issues in European Union law}

A number of requirements and procedures related to the regulation of public participation can be traced to the Directives of the European Union:

1. "Public" and "members concerned of the public" are differentiated. The analysis of dozens of EU directives shows that the ratio of these categories is in line with the recommendations of the Aarhus convention (see, for example, Directive of the European Parliament and Council of the European Union 2010/75/ES dd. November 24, 2010 on industrial emissions (integrated pollution prevention and control));

2 . The list of processes in which the participation of members of the public concerned is guaranteed by EU countries. With regard to the scope of the above-mentioned Directive dated November 24, 2010, such areas include, for example, the issuance of a new permit for an emitting installation (Art. 24). The procedures for public participation in the making of such decisions and provision of information are regulated in detail. In other Directives it is possible to trace the same set of forms and methods of public participation in making environmentally significant decisions, including consideration the citizens' opinions as regards the planning of new enterprises (their modifications); building other potentially dangerous objects next to them, etc. 
In general terms, the procedures of public participation in making environmentally significant decisions include: the right of the public concerned to express their comments to the competent authority prior to making decisions on the specific project; guarantees of timely consideration of the results of the consultations while making decisions;

3. EU Directives refer to a huge number of areas of environmental activities, where the opinions of the public members concerned are considered. Let's try to develop their scientific classification:

a) Environmental protection in the implementation of certain economic activities (considering the opinions of the public concerned in the management of mining production waste or for pollution prevention due to industrial emissions);

b) Protection of the environment from various types of natural and man-made disasters (considering the opinions of the public concerned regarding emergencies at accidents involving dangerous substances);

c) Protection of the individual environment components (land, water, forests, etc.) from the negative impact of economic or other activities (for example, the Directive of the European Parliament and Council of the European Union 2000/60/EC dd. October 23, 2000 stipulates the framework provisions of the Union's activities in the field of water policy considering the opinions of the public).

Thus, international and European law govern three important aspects of public participation in making environmentally significant decisions: the concept (terms), forms and methods of participation, economic and other spheres of activities, which may cause harm to the environment and warrant consideration of the public's opinions.

\section{PROBLEMS OF PUBLIC PARTICIPATION IN SOLVING ENVIRONMENTAL PROBLEMS AT THE DOMESTIC LEVEL (CONSIDERING THE EXAMPLE OF RUSSIA)}

\subsection{Theory and practice of public participation in solving environmental problems in the Russian Federation}

In Russia the possibility of public participation in making environmentally significant decisions is determined in accordance with the Constitution of the Russian Federation and the Federal law dated January 10, 2002 No 7-Ф3 “On environmental protection”.

Despite the formal reference to public participation in making environmentally significant decisions, Russian environmental legislation does not stipulate clear and effective procedures for such participation. Moreover, unfortunately, in trying to use these procedures in order to be listened to, citizens are often persecuted.

This tendency can be illustrated through a couple of examples.

1. Quite a mass tendency appears to be disregard for the civil right to participate in making decisions that are of environmental significance in the question of constructing environmentally-dangerous facilities. Clashes between citizens and organs of public government constantly occur in regard to the construction of waste burning plants, roads, power stations, etc.

In recent years the strongest public response in Russia was caused by two such clashes in regard to the construction of a highway through Khimki forest (Moscow region) and a nickel plant in Prihoperie (the border between Voronezh and Volgograd regions).

In the first case, the situation began during the period July 14-23, 2010 when Khimki forest activists held a rally against the company "PA Teplotechnic" that was cutting down 
the forest without any documented permissions allowing such activities. In September 2010 the company "PA Teplotechnic" filed a claim in the Savelovsky district court, asking ecological activists for compensation totaling $8 \mathrm{mln}$. roubles, the cost of damaged construction equipment. During the court sessions, arguments of the company were unconvincing, and a lawsuit was dismissed. Ecological activists demonstrating against road situated on the chosen route were repeatedly abused and intimidated. This harassment included the beating of road construction opponents, organized bandit assaults on a peaceful forest defenders' camp, as well as inadequate acts of law enforcement in relation to forest defenders. All activists' attempts to obtain a permit for investigation of those cases ended in nothing (Report of the Council under the President of the Russian Federation, 2012).

In the second case the Federal Agency of Subsurface Management held a tender for nickel-field exploration and an extension of the Yelansky and Elkinsky fields on May 22, 2012. According to the tender results, in 14.5 years a mining enterprise is planned to be built in the Novokhopersky district. The 450 thousand tons of nickel is projected to be unearthed. Perspectives of the extension of these fields have become the source of increasing public concern not only in the Voronezh region, but also in the Volgograd region. ${ }^{3}$ Thus, according to public opinion, the plant construction will deal a serious blow to natural complexes in the Khopersky national park. The public hardly has any access to international and domestic audit results, nor the report system concerning the nature protection activities of the enterprise "Norilsky Nickel". Public authorities take no interest in public opinion about the plant construction and openly ignore constant protest rallies.

2. Public ecological associations have tried to take part in decision-making concerning the restriction of public access to natural resources, as well as protest against the construction of official residences in natural parks or other specially protected natural areas. Russian ecological legislation does not strictly regulate those procedures, and law enforcement authorities punish protesters cruelly.

Thus, on February 27, 2011, 25 activists of the public organization "Ecologic guard post of North Caucasus" inspected the territory and found out that forest land as well as the beach line, which should have been open to public, were enclosed with a fence. Public activists of the "Ecologic guard post of North Caucasus" revealed that during the construction of the fence and other structures within the fenced territory, ecological expert proceedings were not kept, permits for the felling of trees included in the Red Book of the Russian Federation were not obtained. Despite repeated appeals to organs of public government, including the Administration of the President of the Russian Federation, illegal fencing continued during the year 2011. In order to get to the territory of the forest fund, in November 2011 citizens had to demount one of the sections of the fence on the illegally occupied land.

As a result, a criminal case was initiated against environmental specialists, as the fence "lost its esthetic qualities" because of inscriptions and could no longer be used as an enclosure of light-gray colour on the front and khaki colour on the back side. Damage to the unique fence was estimated at 119063 roubles 13 kopecks. It was enough to convict E. Vitishko and S. Gazaryan for a term of 5 months' imprisonment (Report of the Council under the President of the Russian Federation, 2012).

${ }^{3} \mathrm{Cf}$. Continuation of a discussion to construct a nickel plant in Volgograd, http://www.krivoezerkalo.ru/node/10347 (date of circulation 10.10.2013). 


\section{NEW ENVIRONMENTAL THREATS AND CHALLENGES FOR THE 21ST CENTURY AND COUNTERACTIVE ACTIVITIES AT THE INTERNATIONAL AND NATIONAL LEVEL}

The 21 st century has generated new threats for humanity due to its further impact on natural processes. Moreover, if the global community has gained certain tools to deal with "standard" threats to environmental security, in respect of new threats, such measures have not been worked out yet. Let's try to look into them closely with regard to the topic at hand.

\subsection{Environmental risks of genetically modified organisms}

The problem of dealing with genetically modified organisms (hereinafter: GMO) has been sufficiently recognized by the world community. Not trying to list all the international and national regulations on this issue, we note that only at the EU level a number of special directives have been devoted to this issue: Directive 2009/41/ES of the European Parliament and Council of European Union dd. May 6, 2009 on the contained use of genetically modified microorganisms; Directive 2001/18/EC of the European Parliament and Council of European Union dd. March 12, 2001 on the deliberate release into the environment of genetically modified organisms, etc. According to the Directive of the European Parliament and Council of European Union dd. September 22, 2003 No 1829/2003 on genetically modified food and feed, all food products containing GMO components of more than $0.9 \%$ must be labeled.

The national legislators have made efforts to limit the import of products containing GMO, through the creation of "GMO free zones". For example, Austria is a country that is completely free of GMO, and has introduced national bans on the cultivation of transgenic crops; all nine federal provinces of the country have declared themselves GMO-free. Similar laws have been adopted in Greece, Poland and Switzerland; the import of GMO products is limited to a number of provinces of Spain (Zhemchuzhnova, 2013).

However, in Russia the procedures for considering public opinion when making decisions regarding the import or distribution of products produced using GMO are not developed, which is in contrast to European countries.

\subsection{Environmental risks from the use of nanotechnologies}

One of the first official definitions of nanotechnologies was given in 2000 by the US National Science and Technology Council (NSTC), coordinating the special federal research program that defines nanotechnologies through:

1. Research and technology development at the atomic and molecular level within the range of 1-100 nanometers.

2. The ability to control processes at the atomic and molecular level.

3 . The creation and use of devices and systems that have novel properties and function due to the inclusion nanoparticles in them (Coordination of the NNI, 2013).

Nowadays in scientific literature, along with the study of positive commercial prospects due to nanotechnology use, attention is beginning to be paid to the high probability of occurrence of various negative social consequences from its use. These consequences include: the deterioration of the environment and human health; an arms race based on 
nanotechnology, a strengthening of existing problems at a new level, including drug abuse, terrorism, unemployment, etc. ${ }^{4}$

With regard to the legal protection of the environment and human health, the application of nanotechnologies in the manufacturing of electronic equipment, construction materials, food products, perfumes and cosmetics, is of particular interest, as is the effect of the direct application and use of nanotechnologies - through the explosion of nanoparticles and nanomaterials - on the environment throughout the manufacturing process. The problem is that the possible biological effects of nanomaterials entering into the human body are not well examined, although there is evidence of a variety of substances being passed through a nanoparticle environment and being significantly altered - in respect of their physical and chemical properties - in the process, which could mean that they adversely affect the human health in the process of their absorption into the body.

Now it has been proven that human organs and tissues have an unequal ability to accumulate nanoparticles. One of the earliest examples of significant changes in the biological activity of materials in the process of decreasing particle size to the nanometer scale is the ability of asbestos to form nanofibers. This ability makes asbestos far from a harmless material, causing cancer and other diseases (asbestosis) upon prolonged contact with it. For a long time, the real cause of this disease was not specified, and only at the end of the 20th century was it proved that the carcinogenic properties of asbestos were related not to its composition, but to the nano-scale and form of its fibers, and therefore a campaign to replace asbestos with safer materials was launched.

The first individuals, who noticed the harmful features of asbestos, were the sanitaryhealth inspectors at manufacturing enterprises. In 1998-1999 the European Union and France imposed a ban on the use of some forms of asbestos. In 2000-2001 the WTO supported a ban in the European Union. In the United States since the mid-20th century the "asbestos cases" were quite famous; these cases being filed by the workers of asbestos mining and processing enterprises, who came down with lung cancer together with the members of their families (Anisimov, 2012).

This group of cases in the US legal literature is regarded as a typical example of a mass tort, and, along with other categories of cases, it became the basis for the theory of torts (Aleksey P. Anisimov, Alena V. Kodolova, 2010).

Thus, there are examples of prohibiting the use of nanomaterials in history, as well as indemnification by nanotechnology companies.

In recent years, the European Union has begun paying attention to this problem. Thus, the Directive of the European Parliament and Council of the European Union 2012/19/ES dd. July 4, 2012 on waste in connection with electrical and electronic equipment states that nanomaterials safely fixed to large structures, such as electrical circuits, are at risk at some stage of becoming waste through processing. To control the possible risks to human health and the environment arising from the processing of nanomaterials, the European Commission should assess the need for special treatment of such wastes. The regulatory system to counteract the environmental effects of nanotechnology at the national level has been gradually formed. For example, in Russia there is no federal law on these matters, but a number of by-laws classify the products of nanotechnology by the extent of potential hazards, and establish the basis of sanitary-epidemiological expertise. The problem lies in

${ }^{4}$ Cf. Social prospects and nanotechnologization consequences. http://ntsr.info/nanoworld/ simply/index.php?ELEMENT_ID=1568. (date of circulation 10.10.2013). 
the fact that these regulations are not mandatory (for the guidance only), and they do not provide for special measures to inform the public on the environmental effects of nanotechnology applications, and they do not provide for procedures to consider public opinion on this issue.

\subsection{Environmental threats from active intervention in hydrometeorological processes}

The first successful scientific attempt at "seeding clouds" was in 1940 by researchers at General Electric Co., but the company later terminated its activities on rainmaking, because of some doubts surrounding their success.

In the USSR, meteorologists made first attempts to create "good weather" in 1960, when technologies for anti-hail protection were developed. A special agent was introduced at a certain area of a cloud by means of anti-hail rockets, which weakened the hail. Similar measures were used in other countries (USA, Argentina, Armenia, Brazil, France, Germany, Spain), allowing a reduction in the damage to agriculture in several cases.

In 1990, the specialists of the State Committee for Hydrometeorology and Environmental Control (USSR State Committee for Hydrometeorology) developed a new technology for creating favorable weather conditions, and in 1995, after the first large-scale use at the 50th anniversary victory celebration, it has been applied widely. "Weather improving" for military parades in Red Square is made regularly. For example, in 2012 the Russian Air Force dispersed clouds in Moscow before the parade in honor of Victory Day. For these purposes 64 million roubles was spent. Similar actions took place in $2010 .^{5}$

One of the most famous cases of weather control was a set of activities carried out in the Soviet Union to prevent precipitation over Chernobyl nuclear power plant and the adjacent territories, which were heavily contaminated with radionuclides. There was a danger that rainfall in the area near Chernobyl, could wash away radioactive substances into the river Pripyat and Kiev reservoir. To prevent precipitation over Chernobyl nuclear power plant, a specialized meteo-aircraft unit was created under the orders of the USSR State Committee for Hydrometeorology and Environmental Control. They provided clear skies in 1980 over the Olympics in Moscow, and in 1985 at the International Youth Festival. $^{6}$ (Chernobyl Nuclear Power Station documents, 2009.)

Active influence on hydrometeorological processes - the influence on natural processes in order to control them and reduce their potential harm to people and the economy. These influences may be different: cloud or fog control, anti-hail activities, etc.

Active influence on clouds - it is a physical and chemical influence on clouds to cause the precipitation or dispersal of clouds without precipitation. This technology is mainly limited to a change in the cloud phase state while it's "seeding" with some reagents, in particular carbon-dioxide ice, silver iodide or lead iodide smoke. The evaporation of carbon dioxide in super cooled water clouds results in strong cooling (below $-40^{\circ}$ ) and super saturation, leading to crystallization. Clouds become mixed and colloidally instable, resulting in precipitation. There are specific technologies regarding the influence on fog and typhoons.

5 In Moscow 64 million was spent for the dispersal of clouds before the Victory parade. http:// cursorinfo.co.il/news/mivzakim/2012/05/09/10-22/ (date of circulation 10.10.2013)

${ }^{6}$ Cf. Chernobyl Nuclear Power Station documents: Impact on weather over an alienation zone in 1986. http://chernobil.info/?p=1464 (date of circulation 10.10.2013). 
There are reports that the possible effects of influencing hydrometeorological processes for military purposes were examined in the United States and the Soviet Union. For example, U.S. troops artificially induced rainfall during the Vietnam War. In the USSR, the possibility to counter the electronic, optical media and satellite systems of the enemy via weather conditions was studied as well as issues related to the improvement of radio propagation, artificial avalanche triggering, ice breaking. ${ }^{7}$

Currently, a number of the above techniques are widely applied in practice. For example, at present in Ukraine the anti-hail service actively operates in the Autonomous Republic of Crimea and the Odessa region in the sphere of grapes cultivation. ${ }^{8}$ In China, the amount of artificially induced precipitation increases by about 50 billion cubic meters every year. The area of land protected from hail increases annually by $500 \mathrm{th}$. sq. $\mathrm{km}$. in the People's Republic of China. In 2010, weather modifications were performed on an area of more than $3 \mathrm{mln}$. sq. $\mathrm{km} .{ }^{9}$

Special bodies intended to direct activities on the artificial influence of weather have been established in 1502 districts of 266 areas and cities included in 27 provinces, autonomous regions and municipalities of the central subordination of the PRC. The provincial meteorological services have a relatively perfect system of artificial weather modification. ${ }^{10}$ Currently, there are about 150 projects on weather modification, which are being conducted in more than 40 countries. Attempts to use the most incredible methods are being made, for example, through the microwave illumination of clouds, heating them to a plasma state. Some countries (e.g. Belarus) do not practice artificial weather modification (Napolsky, 2012).

The Ministry of Natural Resources and Environmental Protection of the Russian Federation approved an activity plan for adaptation of weather modification technologies in the Sochi area during the preparation and holding of the Olympic Winter Games of 2014. In 2012-2013 research to identify the specific application of these technologies in the Caucasus Mountains was carried out. The specialists of the Federal Service for Hydrometeorology and Environmental Monitoring had a task to adapt cloud dissipation technology to the weather conditions of North Caucasus and overcome the danger of a possible abrupt change in temperature, which is typical for the local climate. This Service also developed proposals for artificial avalanche triggering if the thickness of snow cover is critical, as well as possibilities to use the system of artificial snow. ${ }^{11}$

This is not to say that the massive modification of weather processes has no legal base in Russia and other countries. In Russia, for example, the activities in the field of hydrometeorology and related fields are subject to licensing in accordance with Federal Law No 99-FZ dd. May 4, 2011 "On licensing certain types of activities".

${ }^{7}$ Cf. Active impact on hydrometeorological processes. http://dic.academic.ru/dic.nsf/ ruwiki/1609683 (date of circulation 10.10.2013).

${ }^{8}$ Cf. Fight against hail. http://altfast.ru/1000054844-borba-s-gradom.html (date of circulation 10.10.2013).

${ }^{9}$ Cf. News from the FOBOS. Active impacts on weather in China become the regular phenomenon. http://www.meteovesti.ru/news.n2?item $=63457125684$ (date of circulation 10.10.2013).

$10 \mathrm{Cf}$. The annual increase a precipitation by artificial impact on weather in China. http://earthchronicles.ru/news/2011-11-15-11727 (date of circulation 10.10.2013).

$11 \mathrm{Cf}$. Weather for the Olympic Games will change forcibly. http://sochi-24.ru/sochi-2014/ pogodu-dlya-olimpiady-izmenyat-prinuditelno.201191.37566.html (date of circulation 10.10.2013). 
In compliance with the Regulation on Licensing of Activity in the field of hydrometeorology and other related areas (except the mentioned activity in the course of engineering surveys that are carried out for front end engineering design, construction, reconstruction of capital construction objects), approved by the Decree of the Government of the Russian Federation dated 30.12.2011 No 1216, activities in the field of hydrometeorology and other related areas include the following activities (services):

a) determination of meteorological, airmeteorological, climatological, hydrological, oceanological, heliogeophysical and agrometeorological environmental characteristics;

b) evaluation of air, soil, water pollution and pollution of the interplanetary environment (including radioactive waste);

c) development and submission of prognostic, analytical and design information to consumers regarding the environmental status and its pollution (including radioactive waste);

d) creation and maintenance of data bases in the field of hydrometeorology and other related areas.

It follows that the pending active influence on hydrometeorological processes is not included in this list.

One of the explanations of this fact could include officials' statements that "dry ice and liquid nitrogen used for thundercloud dissipation are harmless for the environment and do not influence the weather since clouds are no longer dissipated". ${ }^{12}$

This approach contradicts 4 ecological laws of Barry Kommoner:

1. "Everything is connected to everything else" - this law reflects the ecological principle of holism (wholeness) and is based on the law of large numbers;

2. "Everything must go somewhere" - a closed circuit of substances is necessary for the stable existence of the biosphere;

3. "Nature knows best" - it is necessary to get closer to nature and at the same time treat ecosystems extremely carefully;

4. "There is no such thing as a free lunch" - the law announces that each new advancement is inevitably followed by a loss of the former (Commoner, 2013).

Terrible meteorological disasters of recent years (floods, typhoons, tsunamis etc.) place the "harmlessness" of forced interference with nature into question. Artificial and constant exposure to the Earth's biosphere cannot but cause disaster on a global scale.

As has been reasonably mentioned in scientific literature, "in the context of international law artificial influence on the weather should be considered in relation to the national boundary regime. Artificial change of naturally set rainfall distribution in this area both decreasingly (cloud dissipation) and, vice versa, increasingly (rain- or snowmaking) carried out within one country, may undoubtedly influence the climate of other, first of all, contiguous states." This question has not yet become the subject of special agreements (Baskin-Baskin 1968: 105).

Thus, without any doubt it is necessary to conduct thorough scientific research concerning the connection between the active interference in hydrometeorological processes and global climate change, and the elaboration of international regulatory legal protection against this burning threat of the 21 st century to the human civilization, which has not so far been perceived by the global community.

12 Cf. Artificial ice, liquid nitrogen and iodated silver will provide good weather to Moscow. http://cybersecurity.ru/prognoz/4189.html (date of circulation 10.10.2013). 
Speaking about international legal cooperation in this field, it is worth noting that activities connected with influence on the weather do not lie in the scope of the United Nations Framework Convention on Climate Change dated 9 May 1992, as this Convention puts emphasis on greenhouse gases and other gas emissions that affect the climate. In other words, what is involved are the long-term negative impacts that have led to climate change. In our case it is the spot influence on weather (environment) that may happen under the conditions of a harsh environment (for instance, influence on the polluted air of Moscow the huge megapolis). That is why, it is extremely difficult to estimate to what extent chemical (or other) influences on the weather affect the environmental status (with the assumption that nobody even tries to do this).

Therefore, it seems necessary to adopt an international convention that, in the first place, strongly forbids local impacts on the weather for the sake of "a vanity holiday", e.g. military parades or winter games in a subtropical climate (as in Sochi). From our point of view, such forced weather changes are reasonable only in the case of serious threats to human life, health or property. Besides, natural science representatives have to determine the maximum permissible levels of negative influence on the environment depending on the property problem solving (for instance, rescuing seeds from hail). It seems that even by economic efficiency the volume of negative impacts on the environment aimed at changing weather conditions cannot be absolute. Otherwise, further climate change for the worse will make the economic and political achievements of other countries and nations irrelevant.

In the course of elaborating such international documents it is necessary to include procedures of public participation in decision-making connected with the influence on hydrometeorological processes in a particular region.

During the development of such international instruments it is necessary to fix the procedures for public participation in decision-making related to the influence on hydrometeorological processes in a particular region.

\section{CONCLUSION}

Public participation in making environmentally significant decisions is a long-established category in international and national law. The public participation structure formulated in the Aarhus convention had a direct effect on the rule-making of the European Union. This principle is also introduced in National legislation, even in countries that have not ratified the Aarhus convention.

We have emphasized three clear regulatory aspects of public participation in making environmentally significant decisions in international and European law: concept (terms), forms and methods of participation, economic and other spheres of activity, which may cause harm to the environment, and where consideration of public opinion is stipulated.

The specificity of Russia lies in the fact that despite the formally proclaimed principles of public participation in making environmentally significant decisions, these rules are ignored by public authorities, and environmental activists trying to exercise their constitutional right to a healthy environment are persecuted.

The analysis of international and national regulations allows the selection of multiple forms of public participation in making environmentally significant decisions. The first and main form of this participation is to provide information on the planned activities and implementation of its public environmental control. Such control can be carried out in two forms: preventive (environmental impact assessment) and current (control over a facility in operation). At the same time, the influence of the public on making environmentally 
significant decisions can occur in the form of environmental public rallies, pickets and demonstrations, referenda, appeals to the court or state authorities, as well as other forms.

The 21 st century has determined the origination of new environmental threats that are equally typical for both developed and developing countries on which the international law has no adequate protective measures. The article shows the environmental risks of GMO, nanotechnology, and the consequences of hydrometeorological process modifications. The participation of the international community in the development of the necessary documents, and effective control mechanisms for the participation of the public in making environmentally significant decisions, is one of the most urgent tasks of the leading countries in the world at present.

\section{REFERENCES}

Anisimov, A.P. (in Russian) (2012): Environmental protection from the negative impact of nanotechnologies. Agrarian and land law 5: 93-95.

Anisimov, A.P.-Kodolova, A.V. (in Russian) (2010): Problem of realization of the rights to compensate health injuries caused by widespread technical accidents in Russia and the USA (comparativelegal analysis). European Journal of Natural History 1: 34-36.

Baskin, Y.Y.-Baskin, A.Y. (in Russian) (1968): International legal aspects of artificial weather modification. Jurisprudence 4: 105.

Belokrylova, E.A. (in Russian) (2006): Environmentally significant decisions: concept, content, types. Bulletin of Udmurt University. Jurisprudence 6: 173-176.

Belokrylova, E.A. (in Russian) (2007): Legal forms of public participation in the development, adoption and implementation of environmentally significant decisions regarding the objects for destruction of nuclear and chemical weapons: avtoreferat dissertatsii candidata iuridicheskikh nauk. Izhevsk: Udmurt state university, 18-21.

Brinchuk, M.M. (in Russian) (2000): The legal mechanism for development and adoption of environmentally significant decisions. State and Law 9: 38-52.

Commoner, B. (in Russian): http://ru.wikipedia.org/wiki/Бэрри_Коммонер (date of circulation 10.10.2013).

Coordination of the NNI. http://www.nano.gov/about-nni/what/coordination (date of circulation 10.10.2013).

Gogaeva, M.T. (in Russian) (2011): Legal mechanism for making environmentally significant decisions: avtoreferat dissertatsii candidata iuridicheskikh nauk. Moscow: Institute of the state and law Russian Academy of Sciences, 8-9.

Napolsky, H. (in Russian) (2012): Belarus doesn't practise an active impact on weather. http:// argumentiru.com/meteo/2012/02/159725 (date of circulation 10.10.2013).

Petrenko, V.F. (in Russian) (1998): The legal regulation of social control in the field of environmental protection (in terms of destruction of chemical weapons): avtoreferat dissertatsii candidata iuridicheskikh nauk. Saratov: Saratov Academy Law, 13.

Report of the Council under the President of the Russian Federation for Civil Society Institutions and Human Rights (2012) "Ensuring the rights of citizens to a healthy environment. The main problem. Possible solutions." Moscow, 6-7.

Tikhomirov, Y.A. (in Russian) (1995): Public Law. Moscow: BEK publishing house. 55.

Vasilieva, M.I. (in Russian) (2003): Public interests in environmental law. Moscow: Moscow State University, 316-317.

Veselov, A.K. (in Russian) (2005): Public Environmental Control in Russia: legal regulation and practice (guidelines for public inspection). Moscow: International social-and-ecological union, 37. 
Vinokourov, Y.E.-Vystorobets, E.A. (in Russian) (2010): Public participation in making environmentally significant decisions (legal aspect): Research report, Moscow: Moscow University of the Humanities Publishers, 9.

Zhemchuzhnova, E.A. (in Russian) (2013): The legal regulation of GMO use in the territory of the Russian Federation. New Legal Conception, 127-128. 